\title{
Infiltrating regulatory $T$ cell numbers is not a factor to predict patient's survival in oesophageal squamous cell carcinoma
}

\author{
T Yoshioka*,', M Miyamoto', Y Cho', K Ishikawa', T Tsuchikawa', M Kadoya', L Li', R Mishra', K Ichinokawa', \\ Y Shoji', Y Matsumura', T Shichinohe', S Hirano', T Shinohara ${ }^{2}$, T Itoh ${ }^{3}$ and S Kondo' \\ 'Department of Surgical Oncology, Division of Cancer Medicine, Hokkaido University Graduate School of Medicine, N-15, W-7, Sapporo, Hokkaido 060- \\ 8638, Japan; '2Department of pathology, Teine Keijinkai Hospital, Hokkaido 060-8638, Japan; ${ }^{3}$ Department of pathology, Hokkaido University Hospital, \\ Hokkaido 060-8648, Japan
}

\begin{abstract}
CD4/8 status has been previously reported to be a critical factor in the prognosis of oesophageal squamous cell carcinoma (OSCC). In the current study, we investigated the effect of regulatory $T$ cells $\left(T_{\text {reg; }}\right.$ Foxp $3^{+}$lymphocytes) on the status of CD4 ${ }^{+}$and $C D 8{ }^{+}$ $T$ cells in 122 patients with OSCC. Immunohistochemical analysis of $\mathrm{T}_{\text {reg }}$ was performed using an antibody against Foxp3. The survival rate for low Foxp3 patients was significantly lower than for high Foxp3 patients ( $P=0.0028$ by log-rank test), but Foxp3 status did not significantly correlate with prognosis in $C D 4 / 8(+/+)$ patients or $C D 4 / 8(+/-)$ or $(-/+)$ patients $(P=0.5185$ and 0.8479 , respectively, by log-rank test). We also found that Foxp3 status correlated with CD4/8 status $\left(P=0.0002\right.$ by $\chi^{2}$ test) and that the variance of CD8/CD4 ratio in patients with low Foxp3 was larger than in patients with high Foxp3 ( $P<0.000$ I by F-test). Thus, the results do not support the idea that $T_{\text {reg }}$ suppress anti-tumour immunity in patients with OSCC. Rather, the CD8/CD4 ratio and CD4/8 status appear to be critical factors in anti-tumour immunity. Furthermore, $T_{\text {reg }}$ numbers correlate with both the CD8/CD4 ratio and the CD4/8 status, suggesting that $T_{\text {reg }}$ number is not a factor to predict patient's survival in OSCC. British Journal of Cancer (2008) 98, I258- 1263. doi:I0.1038/sj.bjc.6604294 www.bjcancer.com

Published online 18 March 2008

(c) 2008 Cancer Research UK
\end{abstract}

Keywords: OSCC; Foxp3; $T_{\text {reg; }}$ anti-tumour immunity; prognosis

In previous studies, we found that cooperation between $\mathrm{CD}^{+}$and $\mathrm{CD}^{+} \mathrm{T}$ cells appears to drastically improve the prognosis of patients with oesophageal squamous cell carcinoma (OSCC) (Cho et al, 2003). Thus, the host immune response against cancer cells appears to play a critical role in the inhibition of recurrence and determines the postsurgical prognosis in OSCC. Recent reports suggested that thymic-derived $\mathrm{CD} 4{ }^{+} \mathrm{CD} 25^{+}$regulatory $\mathrm{T}$ cells $\left(\mathrm{T}_{\text {reg }}\right.$; Foxp $3^{+}$lymphocytes) participate in the control of tumour immunity, but whether $\mathrm{T}_{\text {reg }}$ control tumour immunity in OSCC has not been established.

$\mathrm{T}_{\text {reg }}$ represent a minor fraction $(5-10 \%)$ of the CD4 ${ }^{+} \mathrm{T}$ cells, and they maintain immune homoeostasis in immunotolerance and control autoreactive $\mathrm{T}$ cells. In addition to their role in autoimmunity, $\mathrm{T}_{\text {reg }}$ participate in transplantation tolerance and tumour immunity. Although the mechanisms of suppression by $\mathrm{T}_{\text {reg }}$ remain to be determined in vivo, many investigators have reported that $\mathrm{T}_{\text {reg }}$ can inhibit immune responses mediated by $\mathrm{CD} 4{ }^{+} \mathrm{CD} 25^{-} \mathrm{T}$ cells and CD8 ${ }^{+} \mathrm{T}$ cells in vitro via cell-cell contact (Sakaguchi et al, 1995; Sakaguchi, 2000; Shevach, 2002; Camara et al, 2003; Anatomy et al, 2005). $\mathrm{T}_{\text {reg }}$ express CD25 (interleukin-2 receptor $\alpha$ ), glucocorticoid-induced tumour necrosis factor receptor, and cytolytic T lymphocyte-associated antigen 4 on their

*Correspondence: Dr T Yoshioka;

E-mail:yoshioka-t@hakochu-hp.gr.jp

Received 6 November 2007; revised 31 January 2008; accepted 7

February 2008; published online 18 March 2008 surface. The nuclei of these cells also contain Foxp3, which is a member of the forkhead or winged helix family of transcription factors. Foxp3 is reported to be a key regulatory gene for the development and function of $\mathrm{T}_{\text {reg }}$ and the most specific marker of $\mathrm{T}_{\text {reg }}$ (Chatila et al, 2000; Brunkow et al, 2001; Mchugh et al, 2002; Fontenot et al, 2003; Hori et al, 2003; Khattri et al, 2003; Fontenot and Rudensky, 2005).

Several studies in mice have shown that $\mathrm{T}_{\text {reg }}$ inhibit the antitumour immune response (Onizuka et al, 1999; Shimizu et al, 1999; Nishikawa et al, 2005) and that depletion of $\mathrm{T}_{\text {reg }}$ can enhance effector T cell anti-tumour responses (Sutmuller et al, 2001; Tanaka et al, 2002). Additional studies have reported that the $\mathrm{T}_{\text {reg }}$ population increases in peripheral blood and tumour tissues from patients with several types of human cancer (Woo et al, 2001; Liyanage et al, 2002; Ichihara et al, 2003; Curiel et al, 2004; Kawaida et al, 2005; Ormandy et al, 2005), but the relationship between the $\mathrm{T}_{\text {reg }}$ population and the prognosis has not been clarified in OSCC. The purpose of this study, therefore, was to determine the effect of $\mathrm{T}_{\text {reg }}$ on $\mathrm{CD}^{+}{ }^{+}$and $\mathrm{CD} 8{ }^{+} \mathrm{T}$ cells in OSCC. The present study was performed with same cohort as in Cho et al (2003).

\section{MATERIALS AND METHODS}

\section{Patients and specimens}

One hundred and twenty-two patients (105 male and 17 female; mean age, 62.3 years) with primary OSCC underwent radical 
oesophagectomy between September 1989 and May 1999 at the Department of Surgical Oncology, School of Medicine, Hokkaido University or at an affiliated hospital (Department of Surgery, Teine keijinkai Hospital and Department of Surgery, Hokkaido Gastroenterology Hospital). Preoperative examination did not find distant metastasis in any of the patients, and none of the patients had received prior anticancer treatments. Cases of in-hospital death were excluded from the current study. The clinical typing of tumours was determined according to the tumour-node-metastasis (TNM) classification system of the International Union Against Cancer (Sobin and Wittekind, 2002). All tumour specimens were fixed in $10 \%$ formalin and embedded in paraffin wax. One of the deepest sections from each tumour was selected for evaluation, and serial $4-\mu \mathrm{m}$ thick sections were examined by immunohistochemistry. All the informed consent process for immunohistochemical staining were conducted in accordance with the guidelines of the Hokkaido University Institutional Review Board Authorization for this study.

\section{Immunohistochemistry}

For immunohistochemical analysis, formalin-fixed and paraffinembedded specimens were deparaffinised in xylene and dehydrated through a graded series from ethanol to water. For antigen retrieval, sections were floated on $1 \mathrm{~mm}$ EDTA buffer $(\mathrm{pH}$ 9.0) in a plastic container and then heated in a domestic pressure cooker for $3 \mathrm{~min}$ after it reached the maximum pressure. Once cooled, the heat-treated sections were washed three times for $5 \mathrm{~min}$ each with PBS ( $\mathrm{pH} 7.4$ ). Before staining the sections, endogenous peroxidase activity was eliminated by a 20 -min incubation in $0.3 \%$ hydrogen peroxide in methanol. After washing in PBS, specimens were blocked with $10 \%$ normal goat serum (Nichirei Corporation, Tokyo, Japan) for $30 \mathrm{~min}$ and then incubated at room temperature for 60 min with 1:40 mouse anti-human Foxp3 antibody (clone 246A/E7; Abcam, Cambridge, UK) in antibody diluent (DakoCytomation, Glostrup, Denmark). Normal adenoid tissue was used as a positive control for Foxp3. After washing with PBS, the sections were incubated for $60 \mathrm{~min}$ at room temperature with a biotinylated goat antibody to mouse immunoglobulin (Histofine Simple Stain MAX PO [MALTI]; Nichirei Corporation, Tokyo, Japan). After washing in PBS, immunohistochemical staining was developed by incubating the sections in freshly prepared 3,3'-diaminobenzidine tetrahydrochloride (Histofine Simple Stain DAB Solution; Nichirei Corporation) for approximately $10 \mathrm{~min}$. The sections were washed in distilled water, counterstained with haematoxylin for $15 \mathrm{~s}$, and mounted in Permount (Micro Slides; Muto-Glass, Tokyo, Japan). Mouse IgG1 (DakoCytomation, Glostrup, Denmark) was used in place of the Foxp3 antibody for negative controls.

\section{Quantification of $\mathrm{T}_{\text {reg }}$}

Immunohistochemically stained sections were evaluated under a microscope (Olympus Optical Co. Ltd, Tokyo, Japan). The current study was performed in a retrospective manner, but all specimens were evaluated by two investigators blinded to the patients' clinical information. $\mathrm{T}_{\text {reg }}$ were quantified by analyzing five different high power fields $(\times 400)$. Between 0 and $848 \mathrm{~T}_{\text {reg }}$ were detected in the five fields, and the median (109) was used as a cutoff to define the subgroups.

\section{Statistical analysis}

Statistical analysis was performed using the $\chi^{2}$ test. The KaplanMeier method was used to estimate overall survival and survival differences were analysed by the log-rank test based on the number of immune cells. Univariate and multivariate analyses of immune cells and clinicopathological features were performed using the Cox proportional hazard regression model. The F-test was used to analyse the variance in the CD8/CD4 ratio. The Mann-Whitney $U$-test was used to analyse the number of $\mathrm{T}_{\text {reg. }}$. In all cases, $P$-values less than 0.05 were regarded as indicating statistical significance.
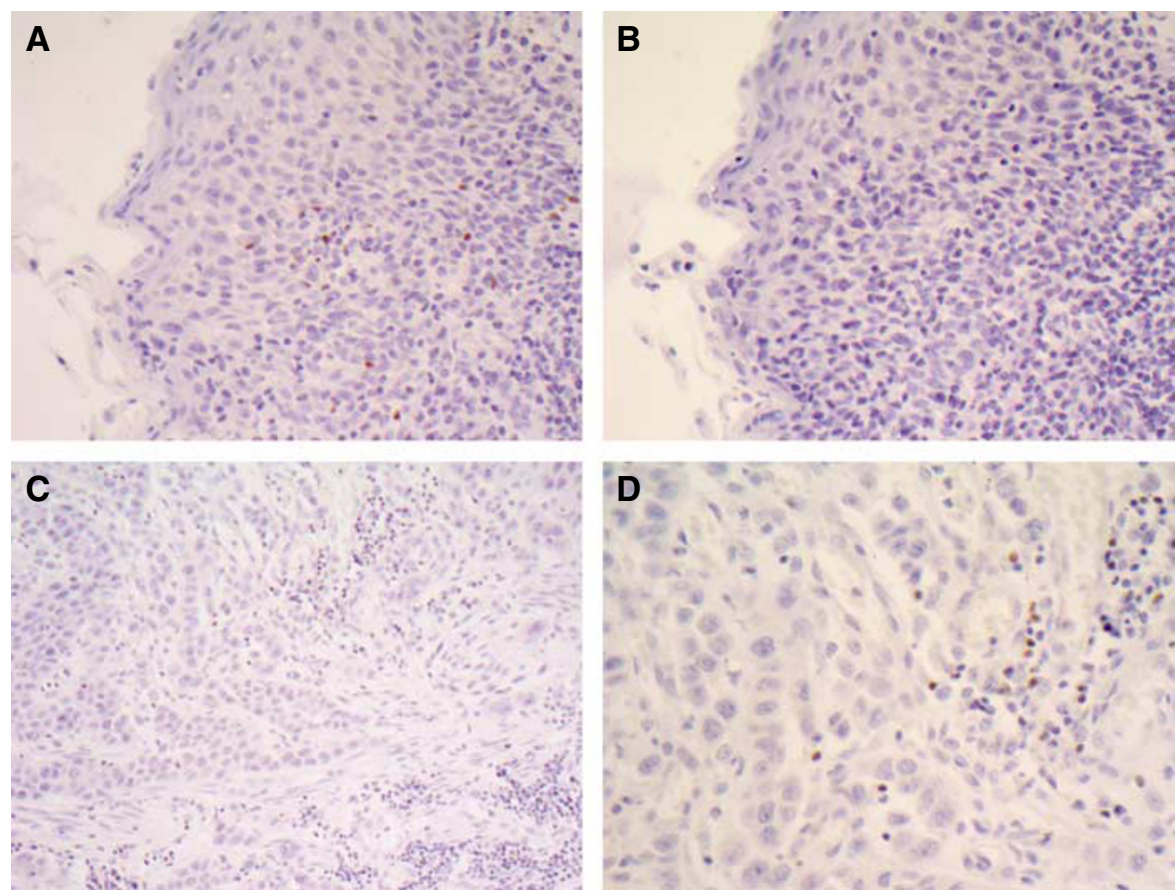

Figure I Immunohistochemical staining. (A) Positive control tonsil stained with anti-human Foxp3 antibody. (B) Negative control tonsil stained with isotype-matched IgG. (C, D) OSCC stained with anti-human Foxp3 antibody at $(\mathbf{C}) \times 200$ and $(\mathbf{D}) \times 400$. 
All statistical analyses were performed using StatView J version 5.0 (SAS Institute Inc., Cary, NC, USA).

\section{RESULTS}

\section{Immunohistochemical staining of $\mathrm{T}_{\text {reg }}$}

Figure 1 shows representative photomicrographs of immunohistochemical staining for $\mathrm{T}_{\text {reg }}$ using an antibody to human Foxp3. $\mathrm{T}_{\text {reg }}$ were detected in cancer cell nests or in the stroma in contact with cancer cells.

\section{Correlation between Foxp3 status and clinicopathological features}

Correlations between Foxp3 status and various clinicopathological features are summarised in Table 1. Foxp3 status was found to correlate with CD4 status $(P=0.0186), \mathrm{CD} 8$ status $(P=0.0021)$, and $\mathrm{CD} 4 / 8$ status $(P=0.0002)$. No significant correlation was found between Foxp3 status and age, gender, pathological data according to TNM classification, or p-stage grouping.

Table I Correlation between clinicopathological features of the 122 patients with OSCC and the number of Foxp3 positive cells

\begin{tabular}{|c|c|c|c|c|}
\hline \multirow[b]{2}{*}{ Variable } & \multirow[b]{2}{*}{ No. of cases } & \multicolumn{2}{|c|}{ Foxp3 positive cell } & \multirow[b]{2}{*}{$P$-value } \\
\hline & & $\begin{array}{c}\text { Low } \\
n=61\end{array}$ & $\begin{array}{l}\text { High } \\
n=61\end{array}$ & \\
\hline \multicolumn{5}{|l|}{ Age (Years) } \\
\hline$<62$ & 58 & 28 & 30 & 0.7169 \\
\hline$\geqslant 62$ & 64 & 33 & 31 & \\
\hline \multicolumn{5}{|l|}{ Gender } \\
\hline Male & 105 & 53 & 52 & 0.7938 \\
\hline Female & 17 & 8 & 9 & \\
\hline \multicolumn{5}{|l|}{ pT classification } \\
\hline $\mathrm{TI} / \mathrm{T} 2$ & 67 & 32 & 35 & 0.5852 \\
\hline $\mathrm{T} 3 / \mathrm{T} 4$ & 55 & 29 & 26 & \\
\hline \multicolumn{5}{|l|}{ pN classification } \\
\hline Negative & 60 & 28 & 32 & 0.4688 \\
\hline Positive & 62 & 33 & 29 & \\
\hline \multicolumn{5}{|l|}{ pM classification } \\
\hline MO & 101 & 50 & 51 & 0.8105 \\
\hline MI & 21 & 11 & 10 & \\
\hline \multicolumn{5}{|l|}{ P-Stage } \\
\hline$|/| \mid$ & 76 & 38 & 38 & $>0.9999$ \\
\hline III/IVA & 46 & 23 & 23 & \\
\hline \multicolumn{5}{|l|}{ CD4 status } \\
\hline Abundant & 61 & 24 & 37 & 0.0186 \\
\hline Scanty & 61 & 37 & 24 & \\
\hline \multicolumn{5}{|l|}{ CD8 status } \\
\hline Abundant & 61 & 22 & 39 & 0.0021 \\
\hline Scanty & 61 & 39 & 22 & \\
\hline \multicolumn{5}{|l|}{ CD4/8 status } \\
\hline CD4/8(+/+) & 44 & 12 & 32 & 0.0002 \\
\hline Others & 78 & 49 & 29 & \\
\hline
\end{tabular}

Kaplan-Meier survival analysis of low Foxp3 and high Foxp3 patients

Survival curves were constructed according to the Kaplan-Meier method (Figure 2). In the 122 patients with OSCC (Figure 2A), the survival rates for patients with low Foxp3 were significantly lower than for patients with high Foxp3 $(P=0.0028$ by log-rank test). In CD4/8 $(+I+)$ patients $(n=44$; Figure $2 \mathrm{~B})$ or $\mathrm{CD} 4 / 8(+/-)$ or $(-I+)$ patients $(n=34$; Figure $2 \mathrm{C})$, Foxp3 status was not significantly related to the prognosis $(P=0.5185$ and 0.8479 , respectively, by log-rank test). In $\mathrm{CD} 4 / 8(-/-)$ patients $(n=44$; Figure 2D), the survival rates for patients with low Foxp3 were significantly lower than for patients with high Foxp3 $(P=0.0050$ by log-rank test). Similar results were found in patients divided into subgroups of p-stages I/II $(P=0.0018$; Figure $2 \mathrm{E})$ and III/IV $(P=0.0352$; Figure $2 \mathrm{~F})$.

\section{Univariate and multivariate analyses}

Univariate analysis for overall survival using a Cox regression model identified $\mathrm{T}$ classification, $\mathrm{N}$ classification, $\mathrm{M}$ classification, CD4 status, CD8 status, and Foxp3 status as significant predictors of the prognosis. Multivariate analysis of the same set of patients was performed for pathological predictors, CD4 status, CD8 status, and Foxp3 status for survival time using the Cox regression model. $\mathrm{T}$ classification, $\mathrm{N}$ classification, CD8 status, and Foxp3 status were of independent prognostic value (Table 2). Although Foxp3 status was not independent when multivariate analysis was performed using CD4/8 status and Foxp3 as factors, Foxp3 status had independent prognostic value in selected cases of $\mathrm{CD} 4 / 8(-/-)$ patients (Hazard ratio $=3.382 ; P=0.0207$; data not shown).

\section{Correlation between CD4/8 status and the number of $\mathrm{T}_{\text {reg }}$}

A significant correlation was found between $\mathrm{CD} 4 / 8$ status and the number of $\mathrm{T}_{\text {reg }}$ by the Mann - Whitney $U$-test (for CD4/8 $(+/+)$ vs $(-/+), P=0.0021$; for CD $4 / 8(+/+)$ vs CD4/8 $(-/-), P=0.0005$; Figure 3$)$. The median value of the number of $\mathrm{T}_{\text {reg }}$ in $\mathrm{CD} 4 / 8$ $(+I+), \mathrm{CD} 4 / 8(+/-), \mathrm{CD} 4 / 8(-/+)$, and $\mathrm{CD} 4 / 8(-/-)$ patients was $203,93,68$ and 67 respectively.

\section{Correlation between Foxp3 status and the variance on CD8/CD4 ratio}

In the 122 patients with OSCC (Figure 4A), the heterogeneity of the variance in the CD8/CD4 ratio was significantly different between high Foxp 3 patients and low Foxp3 patients $(P<0.0001$ by F-test). The variance on CD8/CD4 ratio of low Foxp3 patients (variance: 30.046) was larger than high Foxp3 patients (variance: 0.279 ) in the 122 patients with OSCC. In selected case of CD4/8(-/-), similarly, the variance on $\mathrm{CD} 8 / \mathrm{CD} 4$ ratio was 58.073 in low Foxp3 patients and 0.766 in high Foxp3 patients (Figure 4B).

\section{Kaplan-Meier survival analysis according to the CD8/CD4 ratio}

The patients were divided into four groups according to their CD8/ CD4 ratios (Figure 4C). The survival rates for patients with the highest and lowest $\mathrm{CD} 8 / \mathrm{CD} 4$ ratios were significantly lower than for the other two groups ( $P=0.0026$ by log-rank test). In the CD4/ $8(-/-)$ patients $(n=44$; Figure $4 \mathrm{D})$, the $\mathrm{CD} 8 / \mathrm{CD} 4$ ratio was not significantly related to the prognosis $(P=0.3566$ by log-rank test).

\section{DISCUSSION}

In recent years, factors that regulate immune responses to malignant tumour cells have received a great deal of attention. Several of these studies have shown that $\mathrm{T}_{\text {reg }}$ are recruited to 

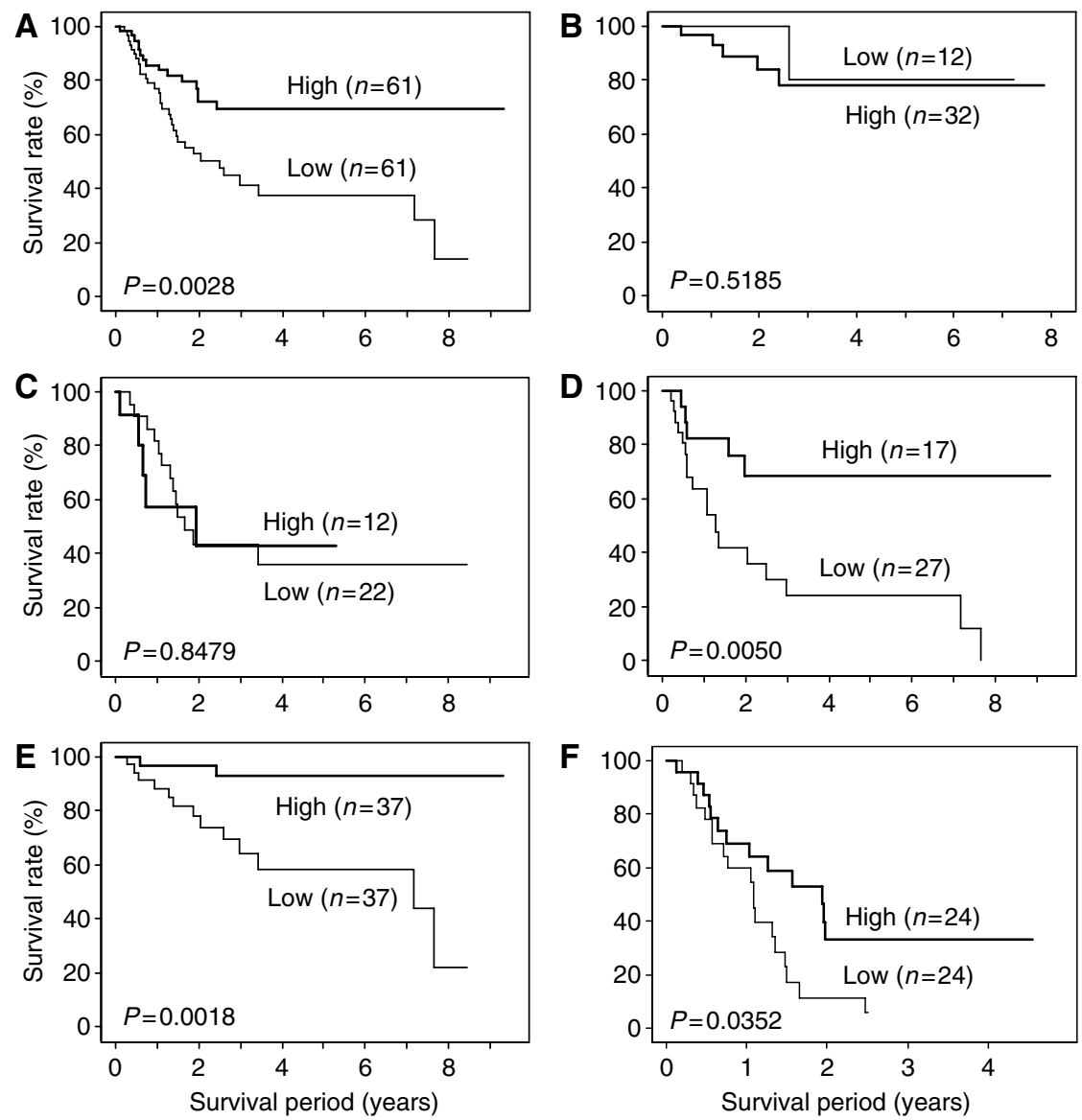

Figure 2 Kaplan-Meier analyses of overall survival according to the number of $T_{\text {regs }}$ in $(\mathbf{A})$ all patients $(n=122),(\mathbf{B}) C D 4 / 8(+/+)$ patients $(n=44)$, (C) CD4/8 $(+/-)$ and $(-/+)$ patients $(n=34),(\mathbf{D})$ CD4/8 $(-/-)$ patients $(n=44),(\mathbf{E})$ stage I and II patients $(n=74)$, and $(\mathbf{F})$ stage III and IV patients $(n=48)$.

Table 2 Univariate and multivariate analyses of immune cells and clinicopathological features using the Cox proportional hazard regression model

\begin{tabular}{|c|c|c|c|c|}
\hline \multirow[b]{2}{*}{ Variable } & \multicolumn{2}{|c|}{ Univariate } & \multicolumn{2}{|c|}{ Multivariate } \\
\hline & Hazard ratio $(95 \% \mathrm{Cl})$ & $P$-value & Hazard ratio $(95 \% \mathrm{Cl})$ & $P$-value \\
\hline Age $(\geqslant 62$ vs $<62)$ (years) & $1.404(0.783-2.519)$ & 0.2543 & & \\
\hline $\mathrm{p}^{\top}$ classification (3/4 vs I/2) & 4.164 (2.238-7.747) & $<0.0001$ & $2.564(1.305-5.038)$ & 0.0063 \\
\hline pN classification (I vs 0) & $5.880(2.885-11.985)$ & $<0.0001$ & $5.051(2.273-11.236)$ & $<0.0001$ \\
\hline pM classification (I vs 0 ) & $3.056(1.615-5.780)$ & 0.0006 & $1.067(0.532-2.141)$ & 0.8556 \\
\hline CD8 status (abundant vs scanty) & $0.451(0.248-0.819)$ & 0.0089 & $0.502(0.259-0.974)$ & 0.0417 \\
\hline Foxp3 status (low vs high) & $2.474(1.338-4.577)$ & 0.0039 & $2.239(1.172-4.275)$ & 0.0146 \\
\hline CD4/8 (CD4/8(+/+) vs others) & $0.208(0.088-0.492)$ & 0.0003 & $0.250(0.130-0.603)$ & 0.0020 \\
\hline Foxp3 status (low vs high) & $2.474(1.338-4.577)$ & 0.0039 & $1.784(0.949-3.353)$ & 0.0722 \\
\hline
\end{tabular}

$\mathrm{Cl}$, confidence interval.

human carcinomas and they may influence the prognosis of cancer patients (Woo et al, 2001; Liyanage et al, 2002; Ichihara et al, 2003; Curiel et al, 2004; Kawaida et al, 2005; Ormandy et al, 2005). To adequately evaluate antitumour immune function; however, multiple factors should be evaluated simultaneously. Here, we found that the $\mathrm{CD}^{+}{ }^{+} \mathrm{T}$ cell effect was significant only when $\mathrm{CD} 4^{+} \mathrm{T}$ cells were also present. This is the first report that has clarified the correlation of $\mathrm{T}_{\text {reg }}$ with $\mathrm{CD}^{+}$and $\mathrm{CD}^{+} \mathrm{T}$ cells in OSCC and examined the effect of $\mathrm{T}_{\text {reg }}$ on these $\mathrm{T}$ cells. In addition, we did not find a correlation between Foxp3 status and TNM classification, suggesting that $\mathrm{T}_{\text {reg }}$ do not influence the progression of cancer.

Based on evidence from murine models, the prognosis of high Foxp3 patients is expected to be poor (Onizuka et al, 1999; Shimizu et al, 1999; Sutmuller et al, 2001; Tanaka et al, 2002; Nishikawa et al, 2005); however the current results do not support this hypothesis because the high Foxp3 patients had a dramatically better prognosis than the low Foxp3 patients. Thus, the increase in $\mathrm{T}_{\text {reg }}$ seemed to be due to an increase in the total number of 
$\mathrm{T}$ lymphocytes, and $\mathrm{T}_{\text {reg }}$ do not appear to suppress the anti-tumour immune response. In fact, the number of $\mathrm{T}_{\text {reg }}$ in $\mathrm{CD} 4 / 8(+/+)$ patients was significantly higher than in CD4/8(-I-) patients and CD4/8 $(-/+)$ patients, and survival curves divided on the basis of Foxp3 status in CD4/8 $(+/+)$ patients were similar. Interestingly, in $\mathrm{CD} 4 / 8(-/-)$ patients, the survival rates for low Foxp3 patients were significantly lower than for high Foxp3 patients. Given these results, it appears that the presence of $\mathrm{T}_{\text {reg }}$ suggested a normal

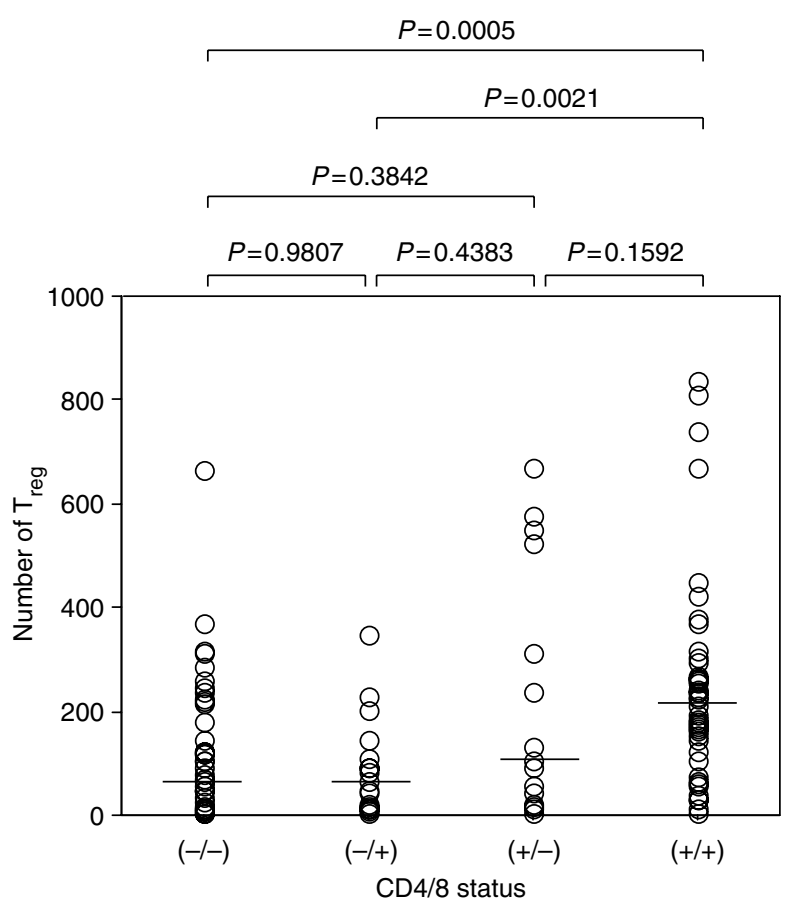

Figure 3 Correlation between CD4/8 status and the number of $T_{\text {regs }}$ The median number of $T_{\text {regs }}$ in CD4/8(-1-), CD4/8 $(-1+), C D 4 / 8$ $(+/-)$, and $C D 4 / 8(+/+)$ patients was $67,68,93$ and 203 , respectively. antitumour immune response, and $\mathrm{T}_{\text {reg }}$ do not appear to inhibit the proliferation of tumour-specific $\mathrm{T}$ lymphocytes. Similar results were shown in patients divided on the basis of p-stage. Curiel et al (2004) reported that tumour cells produce the chemokine CCL22, which mediates trafficking of $\mathrm{T}_{\text {reg }}$ to the tumour and that the percentage of $\mathrm{T}_{\text {reg }}$ in $\mathrm{CD} 4{ }^{+} \mathrm{CD} 3^{+} \mathrm{T}$ cells is higher in the later than the earlier stage of disease; however, we did not find a correlation between p-stage and Foxp3 status, and high Foxp3 patients had a better prognosis in both earlier stage and advanced stage patients. Although the intratumor balance of $\mathrm{T}_{\text {reg }}$ and $\mathrm{CD} 8{ }^{+} \mathrm{T}$ cell has been shown to correlate with prognosis of several cancer types such as ovarian cancer and hepatocellular carcinoma (Sato et al 2005; Gao et al 2007), we did not find a significant correlation between $\mathrm{CD}^{+} \mathrm{T}$ cell/ $\mathrm{T}_{\text {reg }}$ ratio and prognosis. These data also support the idea that $\mathrm{T}_{\text {reg }}$ do not suppress antitumour immunity in OSCC.

Various immunological factors must be considered to understand the state of antitumour immunity. We previously reported that the prognosis of the $\mathrm{CD} 4 / 8(+I+)$ group is remarkably better than that of the other groups (Cho et al, 2003). Around the same time, Diederichsen Axel et al (2003) reported that a high CD8/CD4 ratio is associated with a better prognosis in colorectal cancer. Furthermore, Piersma et al (2007)also reported that a higher CD8/ $\mathrm{CD} 4$ ratio is associated with the lack of tumour metastases in the draining lymph nodes of cervical cancer patients. Therefore, it is obvious that the balance of $\mathrm{CD} 4{ }^{+} \mathrm{T}$ cell and $\mathrm{CD} 8^{+} \mathrm{T}$ cell is critical for prognosis of patients with cancer. In the present study, the favourable prognosis of high Foxp3 patients in the CD4/8(-I-) group appears to be related to the $\mathrm{CD} 8 / \mathrm{CD} 4$ ratio. When the patients were divided into four groups on the basis of the CD8/CD4 ratio, the prognoses of the groups with the highest and lowest ratios were poorer than those of the other two groups. In addition, the CD8/CD4 ratio was disrupted in low Foxp3 patients with poorer prognoses. Similar results were observed in the CD4/8 $(-/-)$ patients. These findings show that a suitable CD4/8 ratio corresponds with a favourable prognosis and that it reflects the immune response against OSCC.

In conclusion, the increase of infiltrating $\mathrm{T}_{\text {reg }}$ in OSCC patients is due to an increase in the total number of $\mathrm{T}$ lymphocytes, and the
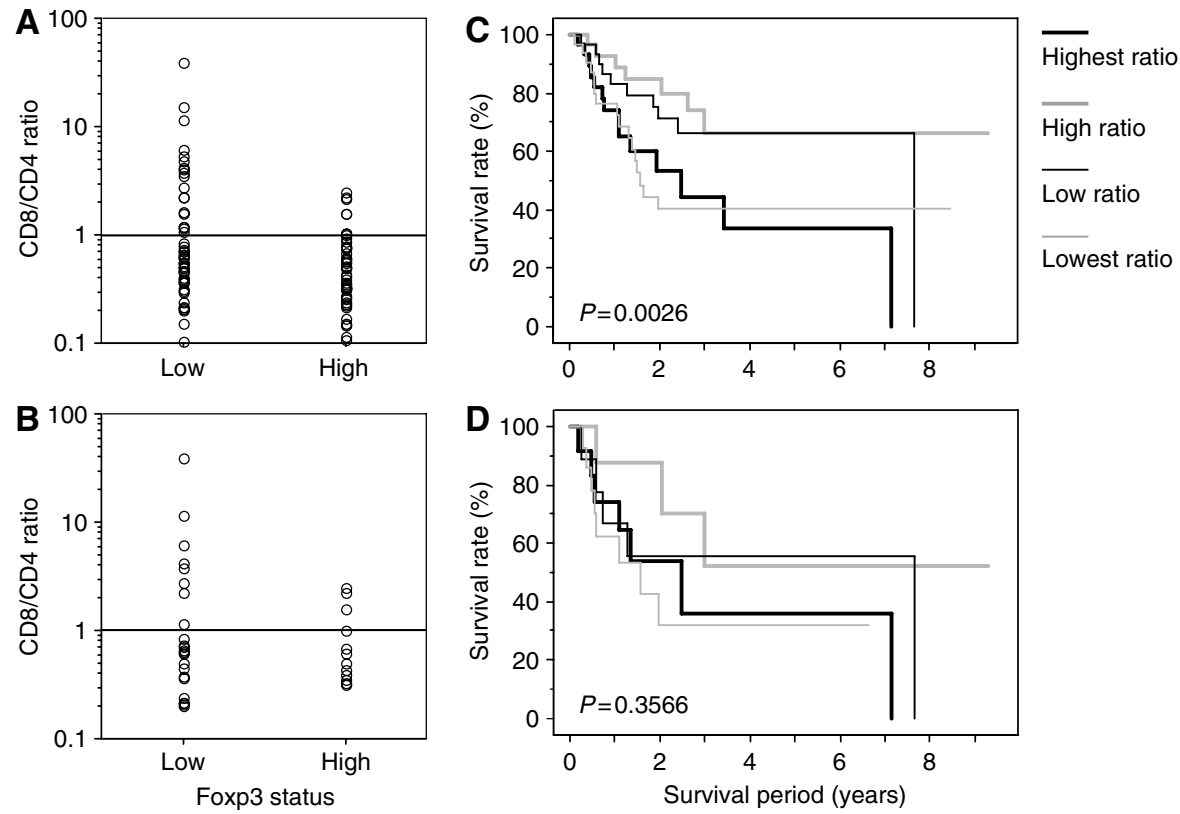

Figure 4 Correlation between the variance in the CD8/CD4 ratio and Foxp3 status $(\mathbf{A}, \mathbf{B})$ and Kaplan-Meier analyses of overall survival relative to the CD8/CD4 ratio $(\mathbf{C}, \mathbf{D})$ in all patients with $\operatorname{OSCC}(\mathbf{A}, \mathbf{C})$ and in $\mathrm{CD} 4 / 8(-/-)$ patients $(\mathbf{B}, \mathbf{D})$. 
results did not support the idea that $\mathrm{T}_{\text {reg }}$ suppress anti-tumour immunity in patients with OSCC. Rather, the CD8/CD4 ratio and CD4/8 status appear to be critical for anti-tumour immunity, and infiltrating $\mathrm{T}_{\text {reg }}$ correlates with both of these measures of antitumour immune function in OSCC.

\section{ACKNOWLEDGEMENTS}

We are grateful to Hiraku Shida and Naomi Saitoh for technical assistance with immunohistochemistry and to the many physicians who cared for the patients at affiliated hospitals of surgical oncology.

\section{REFERENCES}

Anatomy PA, Piccirillo CA, Akpinarli A, Finkelstein SE, Speiss PJ, Surman DR, Palmer DC, Chan CC, Klebanoff CA, Overwijk WW, Rosenberg SA, Restifo NP (2005) $\mathrm{CD}^{+} \mathrm{T}$ cell immunity against a tumor/ self-antigen is augmented by $\mathrm{CD}^{+}{ }^{+} \mathrm{T}$ helper cells and hindered by naturally occurring $\mathrm{T}$ regulatory cells. J Immunol 169: 2591-2601

Brunkow ME, Jeffery EW, Hjerrild KA, Paeper B, Clark LB, Yasayko SA, Wilkinson JE, Galas D, Ziegler SF, Ramsdell F (2001) Disruption of a new forkhead/winged-helix protein, scurfin, results in the fetal lymphoproliferative disorder of the scurfy mouse. Nat Genet 27: 68-73

Camara NO, Sebille F, Lechler RI (2003) Human $\mathrm{CD} 4^{+} \mathrm{CD} 25^{+}$regulatory cells have marked and sustained effects on $\mathrm{CD}^{+} \mathrm{T}$ cell activation. Eur J Immunol 33: 3473-3483

Chatila TA, Blaeser F, Ho N, Lederman HM, Voulgaropoulos C, Helms C, Bowcock AM (2000) JM2 encoding a fork head-related protein is mutated in X-linked autoimmunity-allergic disregulation syndrome. J Clin Invest 106: R75 - R81

Cho Y, Miyamoto M, Kato K, Fukunaga A, Shichinohe T, Kawarada Y, Hida Y, Oshikiri T, Kurokawa T, Suzuoki M, Nakakubo Y, Hiraoka K, Murakami S, Shinohara T, Itoh T, Okushiba S, Kondo S, Katoh H (2003) $\mathrm{CD}^{+}$and $\mathrm{CD}^{+} \mathrm{T}$ cells cooperate to improve prognosis of patients with esophageal squamous cell carcinoma. Cancer Res 63: 1555-1559

Curiel TJ, Coukos G, Zou L, Alvarez X, Cheng P, Mottram P, Hogan ME, Garcia JRC, Zhang L, Burow M, Zhu Y, Wei S, Kryczek I, Daniel B, Gordon A, Myers L, Lackner A, Disis ML, Knutson KL, Chen L, Zou W (2004) Specific recruitment of regulatory $\mathrm{T}$ cells in ovarian carcinoma fosters immune privilege and predicts reduced survival. Nat Med 10: 942-949

Diederichsen Axel CP, Hjelmborg JB, Christensen PB, Zeuthen J, Fenger C (2003) Prognostic value of the $\mathrm{CD}^{+} / \mathrm{CD}^{+}$ratio of tumour infiltrating lymphocytes in colorectal cancer and HLA-DR expression on tumour cells. Cancer Immunol Immunother 52: 423-428

Fontenot JD, Gavin MA, Rudensky AY (2003) Foxp3 programs the development and function of $\mathrm{CD}^{+} \mathrm{CD} 25^{+}$regulatory $\mathrm{T}$ cells. Nat Immunol 4: $330-336$

Fontenot JD, Rudensky AY (2005) A well adapted regulatory contrivance: regulatory $\mathrm{T}$ cell development and the forkhead family transcription factor Foxp3. Nat Immunol 6: 331-337

Gao Q, Qiu SJ, Fan J, Zhou J, Wang XY, Xiao YS, Xu Y, Li YW, Tang ZY (2007) Intratumoral balance of regulatory and cytotoxic $T$ cell is associated with prognosis of hepatocellular carcinoma after resection. J Clin Onc 25: 2586-2593

Hori S, Nomura T, Sakaguchi S (2003) Control of regulatory T cell development by the transcription factor Foxp3. Science 299: 1057-1061

Ichihara F, Kono K, Takahashi A, Kawaida H, Sugai H, Fujii H (2003) Increased populations of regulatory $\mathrm{T}$ cells in peripheral blood and tumor-infiltrating lymphocytes in patients with gastric and esophageal cancers. Clin Cancer Res 9: 4404-4408

Kawaida H, Kono K, Takahashi A, Sugai H, Mimura K, Miyagawa N, Omata H, Ooi A, Fujii H (2005) Distribution of CD4+CD25high regulatory $\mathrm{T}$-cells in tumor-draining lymph nodes in patients with gastric cancer. J Surg Res 124: 151-157

Khattri R, Cox T, Yasayko SA, Ramsdell F (2003) An essential role for scurfin in $\mathrm{CD}^{+} \mathrm{CD} 25^{+} \mathrm{T}$ regulatory cells. Nat Immunol 4: 337-342

Liyanage UK, Moore TT, Joo HG, Tanaka Y, Herrmann V, Doherty G, Drebin JA, Strasberg SM, Eberlein TJ, Goedegebuure PS, Linehan DC (2002) Prevalence of regulatory T cells is increased in peripheral blood and tumor microenvironment of patients with pancreas or breast adenocarcinoma. J Immunol 169: 2756-2761

McHugh RS, Whitters MJ, Piccirillo CA, Young DA, Shevach EM, Collins M, Byrne MC (2002) $\mathrm{CD} 4^{+} \mathrm{CD} 25^{+}$immunoregulatory T cells: gene expression analysis reveals a functional role for the glucocorticoid-induced TNF receptor. Immunity 16: $311-323$

Nishikawa H, Kato T, Tawara I, Takemitsu T, Saito K, Wang L, Ikarashi Y, Wakasugi H, Nakayama T, Taniguchi M, Kuribayashi K, Old LJ, Shiku H (2005) Accelerated chemically induced tumor development mediated by $\mathrm{CD}^{+} \mathrm{CD} 25^{+}$regulatory T cells in wild-type hosts. Proc Natl Acad Sci USA 102: $9253-9257$

Onizuka S, Tawara I, Shimizu J, Sakaguchi S, Fujita T, Nakayama E (1999) Tumor rejection by in vivo administration of anti-CD25 (interleukin-2 receptor $\alpha$ ) monoclonal antibody. Cancer Res 59: 3128-3133

Ormandy LA, Hillemann T, Wedemeyer H, Manns MP, Greten TF, Korangy F (2005) Increased populations of regulatory $T$ cells in peripheral blood of patients with hepatocellular carcinoma. Cancer Res 65: 2457-2464

Piersma SJ, Jordanova ES, van Poelgeest MIE, Kwappenberg KMC, van der Hulst JM, Drijfhout JW, Melief CJM, Kenter GG, Fleuren GJ, Offringa R, van der Burg SH (2007) High number of intraepithelial CD8 ${ }^{+}$tumorinfiltrating lymphocytes is associated with the absence of lymph node metastases in patients with large early-stage cervical cancer. Cancer Res 67: $354-361$

Sakaguchi S, Sakaguchi N, Asano M, Itoh M, Toda M (1995) Immunologic self-tolerance maintained by activated T cells expressing IL-2 receptor $\alpha$ chains (CD25): breakdown of a single mechanism of self-tolerance causes various autoimmune diseases. J Immunol 155: 1151 - 1164

Sakaguchi S (2000) Regulatory T cells: key controllers of immunologic selftolerance. Cell 101: $455-458$

Sato E, Olson SH, Ahn J, Bundy B, Nishikawa H, Qian F, Jungbluth AA, Frosina D, Gnjatic S, Ambrosone C, Kepner J, Odunsi T, Ritter G, Lele S, Chen YT, Ohtani H, Old LJ, Odunsi K (2005) Intraepithelial CD8 ${ }^{+}$tumorinfiltrating lymphocytes and a high $\mathrm{CD}^{+} /$regulatory $\mathrm{T}$ cell ratio are associated with favorable prognosis in ovarian cancer. Proc Natl Acad Sci USA 102: $18538-18543$

Shevach EM (2002) $\mathrm{CD}^{+} \mathrm{CD} 25^{+}$suppressor T cells: more question than answer. Nat Rev Immunol 2: 389-400

Shimizu J, Yamazaki S, Sakaguchi S (1999) Induction of tumor immunity by removing $\mathrm{CD} 25^{+} \mathrm{CD} 4^{+} \mathrm{T}$ cells: a common basis between tumor immunity and autoimmunity. J Immunol 163: 5211-5218

Sobin LH, Wittekind Ch (eds) (2002) International Union Against Cancer. TNM Classification of Malignant Tumors, pp 60-64. Wiley-Liss: New York

Sutmuller RP, van Duivenvoorde LM, van Elsas A, Schumacher NM, Wildenberg ME, Allison JP, Toes REM, Offringa R, Melief CJM (2001) Synergism of cytotoxic T lymphocyte-associated antigen 4 blockade and depletion of $\mathrm{CD}_{2} 5^{+}$regulatory $\mathrm{T}$ cells in antitumor therapy reveals alternative pathways for suppression of autoreactive cytotoxic $\mathrm{T}$ lymphocyte responses. J Exp Med 194: 823-832

Tanaka H, Tanaka J, Kjaergaard J, Shu S (2002) Depletion of CD4 ${ }^{+} \mathrm{CD} 25^{+}$ regulatory cells augments the generation of specific immune $\mathrm{T}$ cells in tumor-draining lymph nodes. J Immunother 25: 207-217

Woo EY, Chu CS, Goletz TJ, Schlienger K, Yeh H, Coukos G, Rubin SC, Kaiser LR, June $\mathrm{CH}$ (2001) Regulatory $\mathrm{CD} 4^{+} \mathrm{CD} 25^{+} \mathrm{T}$ cells in tumors from patients with early-stage non-small cell lung cancer and late-stage ovarian cancer. Cancer Res 61: 4766-4772 